\title{
The links between French school of foresight and organizational learning: an assessment of developments in the last ten years
}

\section{Jean-Philippe Bootz, ${ }^{\mathrm{a}}$ Régine Monti, ${ }^{\mathrm{b}}$ Philippe Durance, ${ }^{\mathrm{c}}$ Vincent Pacini, ${ }^{\mathrm{d}}$ Pierre Chapuy}

a: Lecturer, EM Strasbourg Business School, Université de Strasbourg, HuManiS EA 7308, 61 Avenue de la Forêt Noire, 67000 Strasbourg (France)

b: Associate Professor, CNAM-LIRSA, 292 rue Saint Martin - 75003 Paris (France)

c: Professor, CNAM-LIRSA, head of the Foresight \& Sustainable Development Department

d: Associate Professor, CNAM-PACTE, 292 rue Saint Martin - 75003 Paris (France)

e: Director of Studies, GERPA, research fellow, CNAM-LIRSA, 292 rue Saint Martin - 75003 Paris (France)

\begin{abstract}
The aim of our paper is to provide a comprehensive analysis of current foresight practices and their impact on organizational learning, highlighting recent developments. The analysis is based on around forty foresight projects conducted by the CNAM community of practice in the last ten years or so, based on the typology proposed by Bootz (2003) and Bootz and Monti (2008). The aim is twofold: first, we test the robustness of the initial typology and, second, we examine global developments in foresight practices through an analysis of their cognitive aspects.

The examination of present practice led to the typology being refined, and demonstrates how its impact on organizational learning has been extended. It also shows how discussion has evolved through networks that are more open to the outside world and closer to action, with measures and tools adopted to promote greater flexibility. These changes may be partially explained by the emergence of the knowledge economy.
\end{abstract}

Keywords: Foresight, Organizational Learning, Knowledge Management.

\section{Introduction}

The link between foresight and learning was initially a concern that naturally emerged within the French school due to its specificities. Since the seminal work by Gaston Berger (Durance, 2010), foresight studies have indeed held a unique and specific position within the context of futures research: "It is an authentic concept of its own, rooted in the French worldview" (Valaskakis, 2010, 1464).

Well removed from the normative and determinist approaches of forecasting, it is closely linked to strategic foresight (Godet, 2010) or corporate foresight (Rohrbeck et al., 2015) which considers that there is not just one but several potential futures on which it is possible to act through present actions (Ben Martin, 2010). 
Debates between the 'French style' and the 'American style' (Coates et al., 2010) suggest that there are some differences between "la prospective" and strategic foresight however. The first one views scenarios more as a structuring tool for collective debate (Bootz, 2009; Ringland, 2010) than as a presentation tool (Coates, 2010). It also aimed for a more proactive approach by mobilizing a wide reflection (Godet, 2010), whilst strategic foresight approaches frequently have a more confidential dimension (Vishnevskiy et al., 2015) or are limited to the main stakeholders (Dufva and Ahlqvist, 2015; Cagnin and Keegan., 2008; Miles et al., 2008).

This way of integrating collective reflection and action which characterizes the "French touch" (Lesourne, 2001) is the initial step towards taking into account the importance of organizational learning processes in the foresight approach. From its very first formulation, the foresight attitude reflected the cognitive dimensions of anticipation, in other words, "see far, see wide, analyze in depth" (Berger, 1959, p.218). In terms of foresight activity (Bootz, 2010), we historically find, on the one hand, approaches that focus on strategic planning practices which essentially consider learning as an education process designed for decision-makers (De Geus, 1988; Schwartz, 1991), and on the other hand, approaches that adopt more participative approaches, largely used as tools for collective mobilization (Godet, 2010). In these original works mainly stemming from the French school, learning phenomena are taken into account, but the real nature of the link between foresight and organizational learning remains vague. These works, dating more than 20 years back, were mostly drawn from foresight practitioners and thus suffered from a lack of understanding of the organizational learning processes that were considered at that time as still marginal and complex (Dogson, 1993).

However, in the last 10 years or so, the context has changed. The development of the knowledge economy is now widely accepted (Amin and Cohendet, 2003; Foray, 2009) and throws light on the fundamental role of the learning process (Serenko, 2013). In this context, organizational performance is considered through its capacity to generate, transmit and capitalize on knowledge in order to foster innovation (Foray and Gault, 2003 ; Garvin et al.,2008). This new context has led to the emergence of studies that explore the link between foresight and organizational learning in greater depth and beyond the French school.

The first momentum was given to the subject in 2002 by a conference organised by Tsoukas and Shepherd, entitled, "Probing the Future: Developing Organizational Foresight in the 
Knowledge Economy", ${ }^{1}$ and it has continued to the present day with, for instance, Technological Forecasting and Social Change (TFSC) special issues dedicated to the impact of ICT on foresight (Von der Gracht et al., 2015) and corporate foresight (Rohrbeck et al., 2015). Based on an analysis of around a hundred articles, the latter argue that individual and collective cognition form one of the four major themes of the discipline. This basic shift has resulted in a certain number of studies examining the impact of foresight on knowledge creation and participants representations, frequently underpinned by the classical model of Nonaka and Takeuchi (Uotila et al., 2005; Dufva and Ahlqvist, 2015) and cognitive approaches to learning (Bootz, 2005), with a focus on the impact of scenarios (Glick et al., 2012; Haeffner et al., 2012, Rhisiart et al., 2015) and technology (Boe-Lillegraven and Monterde, 2015).

Recent work (Vecchiato, 2015) has used the literature on organizational learning (approach by routines, knowledge creation model and dynamic capacities) more widely to determine the impact of foresight on strategic agility. Some empirical studies have also looked at the impact of foresight on knowledge exploration and exploitation (Paliokaitė and Pačèsa, 2015).

While such research points to the growing interest in the links between organizational learning and foresight, approaches tend to remain focused on knowledge creation, use organizational learning as an intermediary concept, or else remain largely theoretical. They fail to consider organizational learning in its global dimension. Therefore, the work initiated over 10 years ago by Bootz (2003), followed by Bootz and Monti (2008), who suggested comparing foresight practices within a theoretical framework structured by an extensive review of the literature of organizational learning, continues to shed useful light on this emerging field.

The analysis, based on practices developed through research by the Conservatoire National des Arts et Métiers ${ }^{2}$ (CNAM), focuses on the French school and allows a return to the foundations of the link between foresight and learning processes. This work is based on the construction of a typology that incorporated two criteria (strategic impact and mobilization) to define four types of discriminatory approach in terms of organizational learning: decisionmaking support, strategic orientation, mobilization and change management.

By providing a review of foresight practices in the light of learning theories, this exploratory study shows that beyond its traditional role as a decision support tool, foresight may be

\footnotetext{
${ }^{1}$ The conference gave rise to a book (Tsoukas and Shepherd, 2004a), and a special feature in Futures (Tsoukas and Shepherd, 2004b), together with an overview by Weick (Weick, 2005). ${ }^{1}$

${ }^{2}$ The CNAM fulfills three main missions: higher professional training throughout life, technological research and innovation, dissemination of scientific and technical culture. It offers training developed in close collaboration with companies and professional organizations and runs a network of 29 regional centers and 158 teaching centers in France, headquartered in Paris.
} 
considered as a real knowledge management tool, especially when the approaches are both strategic and participative. However, in the practices of the time, relatively contingent to the scenarios method (Godet, 2007), these approaches appeared more as a seed for change than as a form of generalized practice.

The aim of this study is to take stock of the present French school of foresight and their impact in terms of organizational learning by investigating the changes that have occurred since the first paper was published. To this end, the work by Bootz (2003) and Bootz and Monti (2008) provided us with a framework of present practices based on 45 foresight projects managed by the CNAM community of practice in the last ten years. On the one hand, the aim is to assess the robustness of the initial typology: to what extent are the two criteria (strategic impact and mobilization) still able to discriminate present-day practices? Do we find the same kinds of approaches or can we see the emergence of a new typology?

On the other hand, our study reviews overall changes to the French school of foresight through an examination of their cognitive aspects. We conducted a comparative analysis of the situation now and ten years ago, adopting an empirical approach to identify the main changes and specificities in terms of processes, methods, goals and cognitive impacts, and to appraise today's situation: What have been the main changes in the French school of foresight in the context of knowledge economy? Have methods and processes been created that facilitate organizational learning process?

We begin by presenting a review of the research and the original typology (Bootz and Monti, 2008) that was used as a basis for our comparative analysis. We then present the methodological aspects relative to the CNAM community of practice together with the cases collected. We conclude with our findings and discussion.

\section{Foresight and organizational learning: summary of the typology put forward by Bootz (2003) and Bootz \& Monti (2008)}

An initial exploratory study designed to analyze the impact of foresight on organizational learning was published around ten years ago (Bootz, 2003; Bootz and Monti, 2008). The analysis first involved structuring the field of organizational learning in order to develop a consistent theoretical framework to assess foresight practices. The analysis was then developed by drawing up a typology in an inductive process that involved listing the projects conducted 
within the CNAM community of practice. We deliberately chose to focus our analysis on the field of organizational learning rather than knowledge management in order to respect the terminology used by Bootz (2003) and Bootz and Monti (2008). However in reality, these two fields tend to be more and more strongly correlated ${ }^{3}$ (Farsan, et al., 2013, Prugsamatz, 2010, Pun and Nathai-Balkissoon, 2011).

\subsection{Organizational learning: structuring the literature}

To develop a consistent theoretical framework, the disparate research on organizational learning was structured by a broad and general definition: "knowledge creation processes, the distribution of the latter within the organisation and their inclusion in practices." The notion of knowledge creation incorporates the classic distinction between single loop learning (behavioural approach) and double loop learning (cognitive approach) (Argyris and Schön, 1978). In single loop learning, subjects act to correct a mistake, but without fundamentally changing their representations. It is a continuous improvement learning model within preestablished frameworks, based on repetition (Fiol and Lyles, 1985) that mainly works through trial and error and is underpinned by the notion of organizational routines (Levitt and March, 1988). Double loop learning, on the other hand, involves new action strategies as well as a shift in the system of norms, beliefs and organizational rules when faced with failures or glitches (Argyris and Schön, 1978; Ventriss and Luke, 1988). This form of learning queries the governing variables and mainly concerns top executives (Duncan, 1974). It involves a cognitive process that leads to an enhancement and/or a shift in representations of the world. In line with the work by Leroy and Ramanantsoa (1996), Bootz (2003) and Bootz and Monti (2008) argue that these two forms of learning should not be considered as dichotomous, but rather as complementary forces (Easterby-Smith et al., 2000), providing the means to achieve complete learning.

The second idea within the definition, namely "the distribution of knowledge within the organisation and its inclusion in practices" reflects situated perspective of learning (Lave, 1988; Brown and Duguid, 1991; Wenger, 1998), especially the approach to the organization as

\footnotetext{
${ }^{3}$ Knowledge management (KM) indeed considered in its origin, knowledge as a notion close to information and focused on codification processes (Alavi et al. ; 2005, Spender, 2008). The changes that the KM is going through, in particular taking into account the personalization logic (Hansen et al., 1999) will lead to revising its position by further integrating the tacit knowledge dimension and the learning processes. The KM thus progressively moves from a theoretical field anchored in Information System Management towards an increasingly strong convergence towards organizational learning (Serenko, 2013, Serenko and Dumay 2015).
} 
'a community of heterogeneous communities' (Cohendet et al., 2001; Cohendet et al. 2006; Bogenrieder and Noteboom, 2005; Bootz and Kern, 2009). These studies collate communities defined and governed by 'traditional' hierarchical mechanisms (functional groups and multidisciplinary teams) with communities that are more autonomous in terms of their composition and objectives (communities of practice and epistemic communities). The community of practice $(\mathrm{CP})$ is comprised of homogeneous members who share the same practices and pursue a shared goal of continuous improvement through joint reflections on the practices in place, notably embracing a negotiation of meaning process (Wenger, 1998). These communities are self-organised as their members participate freely to develop their individual skills (Bootz, 2015).

For Cowan et al. (2000), epistemic communities (EC) bring together groups of heterogeneous agents with a common cognitive goal of knowledge creation (Cohendet and Diani, 2003; Cohendet et al., 2001; Cohendet et al., 2006). The community's cohesiveness is ensured by the creation of a 'codebook' and the existence of a procedural authority. ${ }^{4}$ Organizational learning is thus linked to forms of interaction between ECs, geared towards the exploration of knowledge, and CPs which focus on their exploitation (Noteboom, 2006). Cohendet et al. (2003) distinguish between two different forms of interaction in this area. In 'mode 1', communities responsible for creating new knowledge (EC) are disconnected from the activities and practices that their knowledge targets. Consequently, they are isolated departments that produce and distribute the knowledge to other departments that use it to enhance their activities (CPs, functional groups).

'Mode 2' is mainly based on the interactions between two autonomous communities. In this context, communities in charge of creating new knowledge (EC) and the communities that use it (CPs) are paired, simultaneously dealing with the production and circulation of knowledge, and promoting its inclusion in practices.

\subsection{Typology based on the CNAM community of practice}

In order to understand and structure the disparate nature of foresight practices (Bootz, 2010), a typology was drawn up based on practices developed around a dozen years ago within the

\footnotetext{
${ }^{4}$ The procedural authority is defined as a series of rules that define the aims of the community and the resources to be used to achieve them. It also governs group behaviours within the community.
} 
$\mathrm{CNAM}^{5}$ community of practice. At that time, the latter was a major platform for discussion and reflection for the various foresight players (teachers, researchers, consultants and former students). Since the analysis focused on this specific community, it meant that the research concentrated on France and a specific type of practice, largely based on applications contingent to the scenarios method (Godet, 2007) that was very widespread at the time.

The CNAM practitioners identified two main dimensions as discriminatory in terms of foresight practices:

- $\quad$ strategic impact: Does the foresight reflection lead directly or indirectly to strategic activities? Strategic activities are understood in the sense of actions that are difficult to reverse, that focus on the long term, and involve a shift in the organizational framework,

- degree of mobilization: Does the foresight reflection involve a limited number of participants, mobilizing only a small think tank, or does it involve a large proportion of organisation members in the framework of participative approaches?

This dual distinction led to the identification of four types of approach: decision support, strategic orientation, mobilization and change management.

\subsection{The four types of approach to foresight}

\subsubsection{Decision support}

In this type of process, outcomes from the foresight reflection are used to support decisionmaking in the same way as other tools (monitoring, technical-economics studies, business intelligence...). Such approaches generally involve a central think tank made up of internal and external experts, sometimes guided by one or several methodological experts, but without a steering committee. ${ }^{6}$

\footnotetext{
${ }^{5}$ This community, developed in the context of the CNAM Foresight Department, is similar to a CP insofar as its members meet regularly to try to improve their activity by discussing their practices. To this end, they work from a shared register built up over the years, largely based on prospective methods and mutual commitment. The members participate voluntarily and the organisation is designed to enable them to improve their individual skills, giving this social structure a self-organised nature.

${ }_{6}$ The aim is effectively to generate relevant information to support decision-making, but without a strong determination to foster action.
} 
The think tank at the centre of the measures governing decision-making support is organised as an epistemic community focused on knowledge creation. ${ }^{7}$ Incorporating a systemic and foresight dimension (Bootz, 2005), the latter leads to the enhancement and/or the calling into question of its participants' representations. Knowledge creation in this case, as Argyris and Schön (1974) argued, is limited to local level. Indeed, findings are not passed on to other members of the organisation, or only in marginal form by the sponsor. They are not incorporated into practices either, given that this type of approach does not lead directly to strategic actions. In this context, the $\mathrm{CE}$ formed by the think tank finds itself isolated from the rest of the organisation, especially the communities expected to use the knowledge developed (mode 1).

\subsubsection{Strategic focus}

The aim of the strategic focus process is to contribute to strategic decision-making by inciting executives to explore different potential futures together. By concentrating discussion on the leadership aspect, the foresight approach attempts to share and/or challenge the current strategic vision (Fransman, 1987). It also contributes to the introduction of strategic actions. In this type of approach, foresight reflections are conducted by a small think tank composed of members of the steering committee.

The group of leaders thus forms an epistemic community and produces knowledge that results in organizational double loop learning. Introducing strategic actions that arise from the process leads to a shift in the organizational framework, but the confidential nature of this type of approach suggests that there is nothing to incite the organisation's members to change their representations of the world. They thus have to adapt to the new organizational framework arising from the strategic change (behavioural learning). Consequently, strategic actions proposed by the hierarchy may face resistance from members of the organisation who have to deal with a "contradictory injunction" phenomenon (Watzlawick, 1991) according to which they are asked to change their behaviour even though their perception of the context remains the same. Nothing therefore ensures that the creation of knowledge will be reflected in the organization's practices, especially as we find ourselves in a cognitive system that corresponds to mode 1 .

\footnotetext{
${ }^{7}$ Collective foresight practices mobilize think tanks made up of disparate representatives, while the tools used form the codebook, and the role of procedural authority is represented by the methodological expert who frames and supports the process.
} 


\subsubsection{Mobilisation}

The widely accepted definition covers any process involving a large number of people that is geared towards a reflection on the organisation's future without a direct strategic purpose. The broad reflection is generally led by several think tanks coordinated by a technical committee. The wide-reaching group reflection gives rise to largely cognitive (double loop) learning. Such extended mobilization means that representatives of functional groups and communities of practice are often involved in the reflections, forming an integral part of the epistemic community. Interaction between the knowledge-producing community and the communities supposed to use it (mode 2) facilitates simultaneous management of knowledge production and dissemination. However, as this type of approach does not lead to direct strategic change, the organizational framework remains unchanged and individuals are not incited to alter their behaviour. The cognitive changes may thus never transfer into action and only have a very limited impact on the organisation.

\subsubsection{Change management ${ }^{8}$}

The aim of change management approaches is to develop actionable results from a strategic perspective, underpinned by foresight reflections that involve a large number of organizational players. The considerable pressures that weigh on change management approaches (capacity to combine strong mobilization with a strategic extension of the reflections) prompt the use of comprehensive mechanisms (several think tanks, steering committee, technical committee...). From the perspective of organizational learning, knowledge creation arising from the "metaepistemic community" formed by all the players involved in the reflection results in double loop learning. The strategies adopted following the foresight discussions lead to a shift in the organizational framework, which individuals need to adapt to by developing behavioural learning. Adaptation to the new strategy is made easier by the fact their involvement in the reflections leads to largely cognitive learning and a 'well-rounded' learning configuration (Leroy and Ramanantsoa, 1996) in which behavioural and cognitive changes are interwoven, reducing the risk of blockage and resistance to change. In addition, dissemination and inclusion in practice of the knowledge developed during the process are supported by the cognitive design

\footnotetext{
${ }^{8}$ The term change management was chosen by Bootz (2003) and Bootz and Monti (2008) in their work in order to qualify a type of foresight approach. In this respect, it should be distinguished, from the fields of research that it can evoke.
} 
of mode 2 that characterizes these approaches, at the same time linking the epistemic communities, the communities of practice and the functional groups.

In short, the typology shows that foresight approaches are all sources of knowledge creation insofar as the group discussions involve at least a small think tank organized as an epistemic community. On the other hand, with regard to the other two aspects of organizational learning, namely, dissemination and inclusion in the practices arising from the new knowledge, the approaches show mixed outcomes, and differ by fostering more or less 'well-rounded' forms of learning and more or less productive interactions between disparate learning communities (Table 1).

Table 1: Summary of the foresight approaches typology (Bootz and Monti, 2008)

\begin{tabular}{|c|c|c|c|c|}
\hline Type of approach & Decision support & Strategic focus & Mobilisation & Change management \\
\hline$\overline{\text { Objective }}$ & Informs strategic reflections & $\begin{array}{l}\text { Sharing and/or questioning of } \\
\text { the strategic vision. }\end{array}$ & $\begin{array}{c}\text { Prepares mindsets for } \\
\text { potential desirable changes }\end{array}$ & $\begin{array}{c}\text { Stategic actions derived } \\
\text { from broad-based collective } \\
\text { reflections }\end{array}$ \\
\hline Mechanism & $\begin{array}{c}\text { Small think tank made up of } \\
\text { internal and external experts } \\
\text { assisted by methodological } \\
\text { experts }\end{array}$ & $\begin{array}{l}\text { Small think tank composed of } \\
\text { decision makers assisted by } \\
\text { methodology experts }\end{array}$ & $\begin{array}{c}\text { Several think tanks } \\
\text { coordinated by a technical } \\
\text { committee }\end{array}$ & $\begin{array}{c}\text { Comprehensive process } \\
\text { comprising a steering } \\
\text { committee, a technical } \\
\text { committee and several think } \\
\text { tanks }\end{array}$ \\
\hline Organizational learning & $\begin{array}{l}\text { Isolated local learning } \\
\text { (participants) } \\
\text { Mode } 1\end{array}$ & $\begin{array}{c}\text { Double loop learning } \\
\text { Behavioural learning } \\
\text { Mode } 1\end{array}$ & $\begin{array}{c}\text { Cognitive learning } \\
\text { Mode } 2\end{array}$ & $\begin{array}{c}\text { Double loop organizational } \\
\text { learning } \\
\text { Well-rounded learning } \\
\text { Mode } 2\end{array}$ \\
\hline Illustrative cases & EDF, GDF, AIF, GIAT & $\begin{array}{l}\text { Renault, MAIF, Boulanger, } \\
\text { AXA, Lafarge, Shell, }\end{array}$ & $\begin{array}{l}\text { BASF Agriculture, } \\
\text { Renault Mides }\end{array}$ & Catholic Education \\
\hline
\end{tabular}

\section{Methodology: data collection based on 45 foresight cases led by the CNAM community of practice in the last 10 years}

\subsection{Changes within the CNAM community of practice}

The original community of practice from which the typology presented below was drawn up has changed in the last ten years, in line with developments at the CNAM Foresight Department which has shifted its focus from 'industrial foresight' to 'strategic foresight' (Durance, 2014). In recent years it has become part of a research centre whose work extends way beyond the confines of management alone. 
Today, the community of practice is comprised of players with two main characteristics:

- first, they work simultaneously in three fields of activity: teaching, research and expertise;

- second, they support organisations in their foresight practices on a broadly participative basis.

The players that make up this community also frequently act as internal consultants within organisations, supporting them in their foresight and strategic reflections.

While the community remains attached to the CNAM Foresight Department as a centre for training and research, and a source of various initiatives, the institutional nature of the community is less evident than twelve years ago, since the members of the community of practice are spread across numerous private and public organisations.

The foresight approaches adopted by the players in this community differ substantially from two other categories of foresight research:

- totally external studies led by experts outside the walls of the organisation and without any internal participation;

- approaches conducted wholly within organisations, without any external support in the processes, content or method.

The CNAM community of practice has its own code of conduct, namely, "to make do with" rather than "to do for". Concretely, the community's players adhere to a position of guide, focusing on the transfer of foresight skills within organisations in terms of both attitude and method.

The community is fundamentally characterized by its support for group reflections on foresight issues, seeking to balance processes, content and methods, and to innovate in all three dimensions, while other communities of practice tend to focus on just one of these aspeccts.

\subsection{Comparing practices over the last decade with the original typology}

Since it was first published, the original typology has been widely disseminated and used within the community of practice in three main areas: i.e. training, research and expertise. Four contributors to the present paper, active members at the heart of the community of practice, 
used the initial typology in order to classify the foresight processes it has taken part in over the last ten years. In total, 45 cases were retained ${ }^{9}$. The list is presented in appendix 1.

Each contributor first placed each case in the initial typology following discussions with the other collaborators involved in the projects. All of the cases were then discussed by the group in a series of meetings (face-to-face, phone and email) which led to an appraisal of views and the emergence of a consensus. It soon became apparent that the original typology was too limited to take all the recent changes of practice into account, particularly the large increase in foresight processes that involve players from outside the organisation, and the considerable development of cases that take foresight approaches through to action. It was therefore essential to adapt the typology by first improving the discriminatory criteria. The changes are discussed in the following section.

\section{Findings}

The analysis of current practices based on our cases led to a revision of the original typology. The discriminatory criteria effectively needed to be revised, with an extra level added to each, generating not 4 but 6 types of approach.

\subsection{Fine-tuned discriminatory criteria}

\subsubsection{Implications of the results: emergence of an intermediary level focused on operational actions}

Recent foresight practices cannot be slotted into a dichotomous vision that just distinguishes between the direct and indirect strategic implications of the results. We now need to add an intermediary level that embraces operational actions. In the present case, this involves approaches whose aim, unlike the strategic focus or that of change management, is not to impact directly on the global strategy but rather to impinge on operational actions. This new category concerns approaches which, without questioning the global strategy, impact on one or several policies in more restricted fields (HR, technology...). Foresight approaches within this context are linked to action plans. Moreover, these approaches are also different from those that have an indirect strategic impact insofar as they involve reflections that effectively lead to concrete actions, rather than exploratory approaches adopted by groups of experts or players who do not

\footnotetext{
${ }^{9}$ The selected cases are those that were directly supported by the authors of the article and concerning organizations outside of local authorities. Thirty studies of territorial foresight conducted within the community during this period were thus eliminated.
} 
directly influence decisions or action. The implications of these conclusions impact at three levels:

- directly on the global strategy

- directly on operational actions

- indirectly

\subsubsection{Mobilization: inclusion of representativeness and emergence of an intermediary level}

The distinction between low and high number of participants (small think tank versus a large proportion of organisation members) in the first typology needs to be fine-tuned. As this criterion is uniquely quantitative and relatively vague, it fails to take current practices into consideration. Changes in practice mean taking the idea of representativeness into account, rather than a single quantitative criterion. A think tank made up of single-player representatives is less effective at mobilizing others than the same number of think tanks represented by multiplayers. $^{10}$

The issue of representativeness also implies that when it is not possible to rally all the representatives in the initial think tank, different types of external mobilization may occasionally take place. In other words, mobilization does not simply mean joint reflections conducted by one or several think tanks, but may adopt diverse forms (interviews with experts, questionnaires...).

We distinguish three levels of mobilization in the new typology:

- Weak mobilization: a small think tank, generally with just one type of player (only experts, deciders or functional managers).

- Medium mobilization: a multi-player think tank (including deciders, managers and/or functional managers within an organisation, and/or involving representatives from several organisations), with occasional contributions from outside the group and an average of 15 to 30 people included in the process.

- Strong mobilization: an extended arrangement similar to medium mobilization but on a larger scale (from 50 to 200 people involved)

\subsubsection{The development of network approaches and opening up to the outside}

\footnotetext{
${ }^{10}$ Here, the differentiation between players is largely based on hierarchical level, the nature of skills and the internal or external character.
} 
The development of reflections in networks open to the outside forms a structuring element of changes to practices. At the time of the first typology, the work documented was virtually all of an internal nature, with two exceptions: BASF agriculture (Chapuy and Gros, 2010) and Catholic education (Bootz, 2003). Today, this type of reflection has developed considerably and represents almost half the cases identified, to the extent that we can split each type of approach into internal/external. In these network or external approaches that draw various players together around a common challenge, we distinguish:

- Those conducted by organisations in networks that must develop strategies and projects for joint long-term actions (chambers of agriculture, federations...).

- Those conducted within organisations that bring stakeholders together around a specific issue such as occupations and skills observatories; they may include company representatives, unions, training organisations, authorized fund collecting and distributing agencies, etc.

- Those conducted by independent organisations on a range of topics. For instance, BASF Agriculture, which drew together players without any institutional links to discuss common challenges, or joint discussions by organisations based on occupation and skills observatories.

\subsection{A typology of 6 approaches}

The increase from 2 to 3 levels for each criterion resulted in 6 instead of 4 types of foresight approach.

\subsubsection{Relatively stable elements}

In the new typology, we find strategic focus and decision-making support approaches with identical characteristics to the first version. Mobilization approaches are split into two categories, depending on the extent of mobilization (medium or strong), without affecting the basis of the approaches. 
The first category is characterized by medium mobilization, with a main think tank that seeks to develop joint representations of the future and to share its analyses of future challenges, as in the case of BASF Agro with sector players, or GDF SUEZ's 'marketing' business unit to prepare its high potentials for the challenges of the digital revolution and energy saving. In this first category, all of the players involved individually analyze the consequences of their actions, irrespective of the group effort.

The second category of approaches is characterized by strong mobilization, which results in the involvement of several think tanks combined with other forms of participation (foresight questionnaire, interviews...). The number of participants in the discussions can reach 30 to 50 people, as in discussions on the future of the profession of architect with all the stakeholders in Toulouse. It may even reach 100 to 200 people, as with Innovation Santé 2025, for example, which brought together over 400 contributors in various configurations (individual contributions: one hundred, foresight seminar: around fifty, questionnaire: around 200, conference: around 200, interactive website...). These approaches aim to develop alternative representations of the future, identify the potential main shared challenges, and the main avenues for possible solutions, with as wide a range of views as possible.

\subsubsection{Major changes}

The most significant developments concern change management approaches that differentiate between strategic change management (or change management in the initial typology) and operational change management. They also include the emergence of a new process that was not present in the original typology, namely, operational focus.

\section{Strategic change management}

While in the initial typology, strategic change management was considered as a difficult to achieve ideal-type, in the last ten years there have been far more foresight approaches with average or strong mobilization, directly resulting in the strategy and/or the business models being challenged. Two categories have been identified according to the extent of mobilization.

The strategic change management approach with an average level of mobilization is characterized by approaches developed jointly by players, generally from the main steering committee think tank, that cover all aspects of strategic foresight: exploration, challenges, 
strategic directions and action plans. Think tank participants are generally deciders, in other words, executive managers (e.g., the directors of the Fondation d'Auteuil institution or the main HR directors for the "Forces terrestres futures 2025" study. The steering committee works with the board of directors for internal affairs, and with the leaders concerned for external affairs. These approaches result in the questioning of strategic orientations, which either leads to projects being ratified, such as the Fondation des apprentis d'Auteuil and its positioning with respect to 14 to 18 -year olds at risk, abandoned by other players in the system, or else results in a change of model as with the mixed economy parking firms which now define themselves as mobility players. They may also steer the strategy in a new direction, as in the case of UNESCO certification for the Caverne Vallon Pont d'Arc (formerly Grotte Chauvet) scheme, where the participative body (made up of civil society groups) suggested boosting the links between the project and the area's production economy to make the south Ardèche development model more robust.

Strategic change management approaches with a high level of mobilization are characteristic of recent evolutions. The development of this type of process is highly mobilizing within firms and organisations, and frequently includes the stakeholders. This lever now appears more essential to the success of any change management approaches.

The latter are underpinned by the high level of mobilization, the number of people involved and the diverse forms of participation. The Agence Française de Développement led a reflection on a 10-year projection (AFD 2025), directly involving around 300 people from a payroll of 1600 in its workshops, seminars, conferences, think tank, etc., without counting the distribution of a comprehensive questionnaire to all the staff (25\% response rate). Extending the representativeness of the people involved in this way generally leads to an even more radical rethink that stimulates innovation. Thus, following the foresight approach of the "Fondation motrice" that examined priority research areas for cerebral palsy, the combined foresight reflections by groups of patients, relatives, therapists and academics led to new priorities in terms of the thrust of research, with the main focus on pain, an area previously neglected by academics, but at the forefront of patients' concerns. ${ }^{11}$

\section{Operational change management}

\footnotetext{
${ }^{11}$ This research avenue remains a priority several years after the end of the prospective discussions.
} 
Operational change management refers to approaches that have a strong impact, not on the global strategy of the organisation(s), but on their policies, such as human resources for Becton Dickinson for example, communications for the CNIEL, or specific mutualizing issues for Brittany's chambers of agriculture.

The specificity of these approaches is that their focus (time spent, effort made) is less to do with the exploratory aspect and more with the issues arising from the sphere concerned (HR, communications, other) and the direct impact on action. Here, we are mainly interested in the interface between external environmental changes and internal issues. The processes are relatively demanding, often involving operational managers and decision makers, with at least one think tank with a high degree of representativeness (managers, support functions...) and a powerful steering committee.

They involve both short-term approaches and those that take the operational nature of the results further. For example, in the case of internally conducted occupations foresight, we need to examine all the key aspects of foresight in any given job: exploration, challenges, impact on skills orientation and HR policies, and impact on HR actions.

\section{Operational focus}

Another new factor in the typology is the appearance of the operational focus. This involves activities mainly managed by players directly involved in the fields concerned, generally grouped within just one think tank. In this category, foresight exercises may be conducted on specific issues. This was true of the "Molécules Vallées" project, conducted by the CCI of Lyon in 2009, to identify strategic plant molecules with a group made up of researchers, institutional players and entrepreneurs from the Rhône-Alpes region. The aim was to prepare players for a future decline in traditional chemicals investment sectors and a green growth model. It was therefore highly operational, but there was no plan to disseminate the results within the organisation beyond the project under study and the immediate decisions to be taken.

A summary of the results can be found in Figure 2.

Figure 2: Typology of foresight practices (2016) 
Figure 2: Typology of foresight practices (2016)

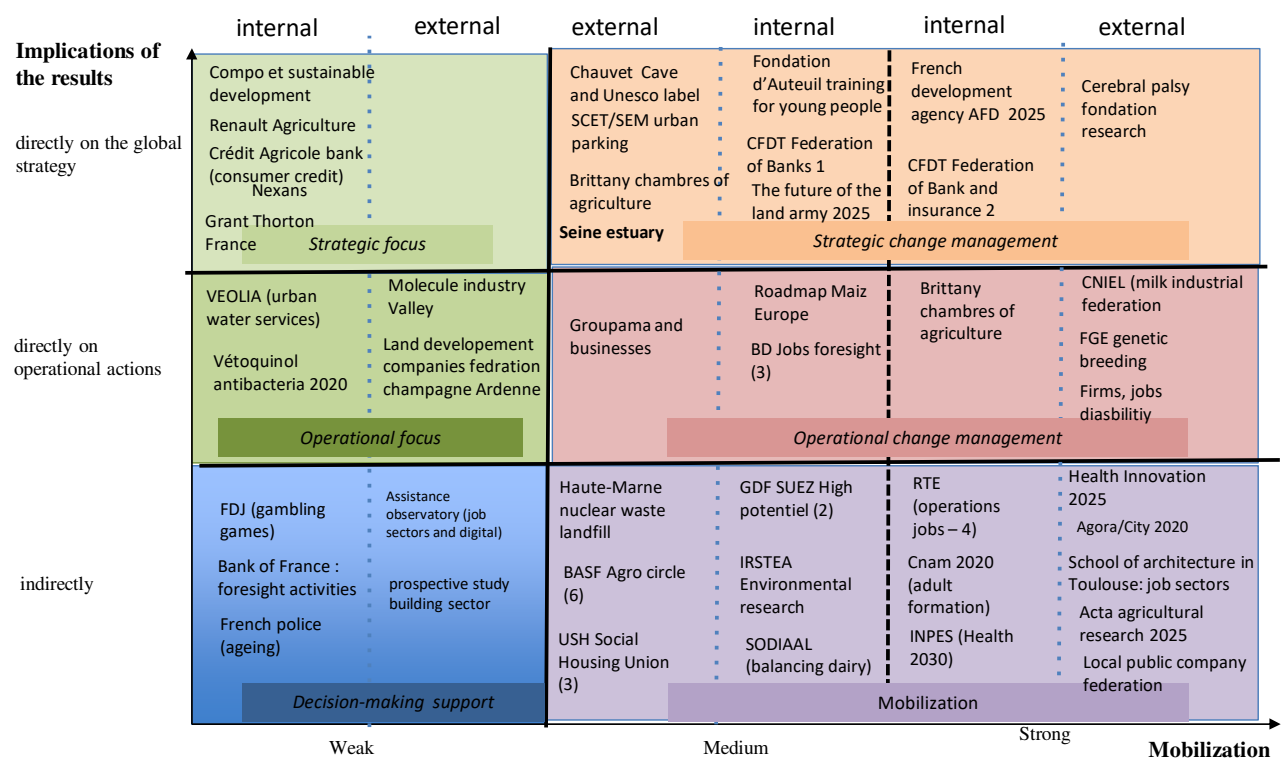

\section{Discussion}

\subsection{Foresight and organizational learning: analysis of the impact of the new approaches}

With regard to the approaches found in the original typology (decision-making support, strategic direction and mobilization), the impact in terms of organizational learning by and large remains the same. Our analysis therefore focuses on the new approaches (operational focus and operational change management) and structural changes (development of network approaches).

\subsubsection{Operational focus and organizational learning}

Operational focus approaches give rise to operational actions without any fundamental changes to the organizational framework since, unlike strategic focus approaches, the aim is not to change the organisation's global strategy, but on their policies. In this case, the knowledge created by the think tank does not lead to double loop organizational learning. The organisation's players must adapt to the operational actions introduced (behavioural learning) without changing their representations since this type of reflection remains restricted to a limited circle (mode 1), which means there is a risk of resistance to change. In short, the 
configuration is very close to the strategic focus, with the key difference that the actions introduced do not call the current strategic framework into question.

\subsubsection{Operational change management and organizational learning}

This type of approach offers more or less the same virtues as strategic change management, in other words, the emergence of a well-rounded form of learning. The extent of the mobilization combined with the implementation of operational actions entails interaction between cognitive and behavioural learning that reduces the risk of blockage and resistance to change. In addition, diffusion of knowledge developed during the process are supported by the interaction between epistemic communities, communities of practice and functional groups (cognitive design of mode 2).

On the other hand, unlike operational change management processes, the changes do not lead to a major strategic upheaval. Reflections occur within an unchanged framework, so no form of double loop learning is created.

\subsection{Development of participative approaches and change management: a major shift supported by the knowledge economy}

10 years ago, change management approaches, although the most 'virtuous' in terms of organizational learning, in practice remained largely in the minority, and at times were even considered as difficult to apply theoretical abstractions. At the time, only a prospective exercise conducted within the Catholic Education sector fully corresponded to this type of approach (Bootz, 2003).

The apparent contradiction can be explained by the fact that this type of approach only concerned a limited number of firms that already developed forms of organizational learning in a more or less intensive way. A decade ago, this type of business was still in the minority. For most 'non learning' or 'hierarchical' organisations, the direct introduction of a change management approach was virtually impossible as it involved a cultural shift that was too radical.

Since then, however, the context has changed dramatically with the arrival of the knowledge economy (Dean and Kretschmer, 2007; Powel and al., 2004). In this context, knowledge 
management has gradually become institutionalized in business organisations. Considered as a driver of innovation and sustainable competitive advantage, practices aiming to develop creation, codification, capitalization and knowledge transfer have developed significantly ${ }^{12}$ (Garvin et al., 2008).

Far more than 10 years ago, this new factor now helps to drive collaborative projects, develop creative structures and guide design processes. Other factors also support this evolution, such as the generalization of work in project mode, the decentralization of organisations, the reduction in hierarchical levels, and shifts in organizational boundaries that are now more open to the outside and more sensitive to external factors Change management approaches have thus developed significantly.

The development of network approaches may also be explained by the major shift impelled by the knowledge economy that pushes businesses to review their borders in order to collaborate with their stakeholders (clients, suppliers, users, rivals...) in a highly competitive environment. The development of innovation ecosystems, crowdfunding (Albors et al. 2008) and, more widely, open innovation (Chesbrough, 2003) is symptomatic of this shift.

Consequently, the resources needed to develop strategies (knowledge, skills, financial expertise...) are increasingly found in organizational ecosystems (globalization of markets, digital developments, legislative changes...). The internal and external intertwining generated by the foresight approach is no longer entirely of the same nature. In this context, approaches to foresight are less likely to be simple exercises involving the development of a foresight system and more liable to involve the construction of frameworks for action (to think and act at other levels with other players) in more open systems. This explains why the construction of a framework for joint action is so important.

\subsection{Evolutions in tools and methods to support these changes}

One of the main features of the changes in foresight processes identified in the CNAM community of practices is the increasingly rare use of formal foresight tools that ane time characterized this community (especially systemic analysis and impact tools combined with structural analysis, the Micmac method or the Mactor method (Godet, 2007), or methods of subjective probability.

\footnotetext{
${ }^{12}$ According to a survey conducted in 2010 by Bain \& Company, almost $40 \%$ of 1160 business leaders questioned said they had set up a knowledge management programme in their organisation (Rigby, 2011). Another study (Forrester, 2008) put this market at almost 4 billion euros, with a growth rate of over $50 \%$.
} 
What remains is a meta-method (Coates, 2010) which now covers most of the work:

- on foresight information according to three avenues: systemic, dynamic temporal, and taking uncertainty into account;

- on the capacity to produce different representations of the future useful for reflection (geared towards action and strategy)

- on the interfaces between external evolutions and internal impacts, with OT-type (threats/opportunities) analyses combined with the temporal dimension of strategy and the evolutions and action frameworks of reference for the organisations involved.

Among the formal tools used in all the cases examined, we mainly identified a simplified version of the morphological analysis to support the collective development of scenarios and survey methods with experts, notably with the Lidoli Abaque method of questioning.

What differentiates foresight approaches today with respect to the different meta-methods are the stages they go through or not to pass from exploration to action. We thus identified six nonsequential key moments:

1) creation of the basis of foresight information (systemic, dynamic temporal)

2) foresight exploration (hypotheses, scenarios) - representations of the future

3) the main stakes (threats and opportunities according to the strategic framework/action framework)

4) impact on strategic focus and the new strategic framework of reference

5) impact on operational strategies and the new operational framework of reference

6) deployment and follow-up

The key moments differ according to the type of approach (see Table 2). For example, in the case of operational change management approaches, the data gathering stage is often poorly developed, with a relatively short sequence at the start on foresight exploration and the issues that serve as a basis for the more comprehensive study phase which focuses on operational strategies. In most cases, this leads to the deployment and follow-up of actions identified over time in the final phase (key feature of this type of approach). In the context of a mobilization process, the focus is different. The steps to draw up the method's basic foresight/exploration data are crucial, while the steps involved in the strategic focus and avenues for optional actions are more secondary. In effect, mobilization approaches are generally exploratory approaches in 
common with possible futures and sharing future issues with internal players or with players from outside the organisation.

This meta-method also incorporates specific approaches that include both the components (steering committee, think tank, different modes of internal and external association...) and their characteristics (number, representativeness, duration, etc.).

Methodology trends thus show a gradual decline in the use of formal tools (scenario type method), replaced by more flexible approaches. The discontinued use of several structured methods can be explained by the determination to move towards more flexible and simpler approaches to meet the demands of organizational pressure. From this perspective, foresight therefore tends to be closer to that of Coates (2010). However, the strategic and/or operational 'collective mobilization' and 'loopback to action' dimensions have developed yet further in recent years, reinforcing the uniqueness of the French school of foresight practices in comparison to US approaches. Globally, this means there is a dual paradoxical foresight movement compared to other foresight approaches.

Moreover, the use of methods which combine collective mobilization, questioning experts and finding other sources of information remains consistent with the vision of many foresight specialists (Haegeman et al, 2013; Lüdeke, 2013; Popper, 2008; Malanowski and Zweck, 2007).

Table 2: Summary of foresight approaches 2016 


\begin{tabular}{|c|c|c|c|c|c|c|}
\hline & $\begin{array}{l}\text { Decision } \\
\text { support }\end{array}$ & Strategic focus & $\begin{array}{l}\text { Operational } \\
\text { focus }\end{array}$ & Mobilisation & $\begin{array}{l}\text { Strategic } \\
\text { change } \\
\text { management }\end{array}$ & $\begin{array}{l}\text { Operational } \\
\text { change } \\
\text { management }\end{array}$ \\
\hline Aim & $\begin{array}{l}\text { Input for } \\
\text { strategic } \\
\text { reflections }\end{array}$ & $\begin{array}{l}\text { Sharing and/or } \\
\text { challenging of the } \\
\text { strategic vision to } \\
\text { clarify the } \\
\text { strategic focus }\end{array}$ & $\begin{array}{l}\text { Preparing local } \\
\text { players/decision- } \\
\text { makers for possible } \\
\text { and desirable } \\
\text { changes to help } \\
\text { develop their } \\
\text { actions }\end{array}$ & $\begin{array}{l}\text { Preparing mindsets } \\
\text { for possible and } \\
\text { desirable changes } \\
\text { (developing } \\
\text { representations and } \\
\text { identifying } \\
\text { challenges) }\end{array}$ & $\begin{array}{l}\text { Developing } \\
\text { strategic focus via } \\
\text { collective } \\
\text { reflections }\end{array}$ & $\begin{array}{l}\text { Developing } \\
\text { strategy in terms of } \\
\text { actions via } \\
\text { collective } \\
\text { reflections }\end{array}$ \\
\hline Implementation & $\begin{array}{l}\text { Small think } \\
\text { tank composed } \\
\text { of internal and } \\
\text { external experts }\end{array}$ & $\begin{array}{l}\text { Small think tank } \\
\text { composed of } \\
\text { decision-makers } \\
\text { aided by } \\
\text { methodological } \\
\text { experts }\end{array}$ & $\begin{array}{l}\text { Think tank } \\
\text { composed of experts } \\
\text { and managers } \\
\text { responsible for a } \\
\text { topic }\end{array}$ & $\begin{array}{l}\text { 1) Small think tank } \\
\text { composed of } \\
\text { decision- } \\
\text { makers/technical } \\
\text { committee managers } \\
\text { and steering } \\
\text { committee } 2 \text { ) } \\
\text { Several think tanks } \\
\text { coordinated by a } \\
\text { technical and } \\
\text { steering committee }\end{array}$ & $\begin{array}{l}\text { Comprehensive } \\
\text { system comprising } \\
\text { a steering } \\
\text { committee, a } \\
\text { technical } \\
\text { committee and } \\
\text { several think tanks }\end{array}$ & $\begin{array}{l}\text { Think tank } \\
\text { comprised of } \\
\text { managers/local } \\
\text { players with } \\
\text { steering committee } \\
\text { and technical } \\
\text { committee or } \\
\text { several groups }\end{array}$ \\
\hline Method & $\begin{array}{l}\text { Database + } \\
\text { Exploration +/- } \\
\text { Challenges+/- } \\
\text { Strategic } \\
\text { orientations- } \\
\text { Action-based } \\
\text { orientations } \\
\text { Deployment } \\
\text { and follow-up - } \\
\text { - }\end{array}$ & $\begin{array}{l}\text { Database - } \\
\text { Exploration+ } \\
\text { Challenges ++ } \\
\text { Strategic } \\
\text { orientations ++ } \\
\text { Action-based } \\
\text { orientations } \\
+/- \\
\text { Deployment and } \\
\text { follow-up - }\end{array}$ & $\begin{array}{l}\text { Database +/- } \\
\text { Exploration }+/- \\
\text { Challenges ++ } \\
\text { Strategic } \\
\text { orientations +/- } \\
\text { Action-based } \\
\text { orientations } \\
++ \\
\text { Deployment and } \\
\text { follow-up? }\end{array}$ & $\begin{array}{l}\text { Database - } \\
\text { Exploration }+/ \\
\text { Challenges }++ \\
\text { Strategic } \\
\text { orientations }+/ \text { - } \\
\text { Action-based } \\
\text { orientations } \\
+/ \text { - } \\
\text { Deployment and } \\
\text { follow-up } 0\end{array}$ & $\begin{array}{l}\text { Database } \\
\text { Exploration ++ } \\
\text { Challenges ++ } \\
\text { Strategic } \\
\text { orientations + } \\
\text { Action-based } \\
\text { orientations } \\
+/- \\
\text { Deployment and } \\
\text { follow-up + }\end{array}$ & $\begin{array}{l}\text { Database +/- } \\
\text { Explortion +/- } \\
\text { Challenges ++ } \\
\text { Strategic } \\
\text { orientations +/- } \\
\text { Action-based } \\
\text { orientations } \\
++ \\
\text { Deployment and } \\
\text { follow-up + }\end{array}$ \\
\hline $\begin{array}{l}\text { Type of } \\
\text { production }\end{array}$ & $\begin{array}{l}\text { Production in } \\
\text { back office } \\
\text { type study }\end{array}$ & $\begin{array}{l}\text { Collective, } \\
\text { leaders and back } \\
\text { office (experts) } \\
\text { production }\end{array}$ & $\begin{array}{l}\text { Collective } \\
\text { production }\end{array}$ & $\begin{array}{l}\text { Core collective } \\
\text { production } \\
\text { +expertise } \\
\text { Extensive external } \\
\text { study }\end{array}$ & $\begin{array}{l}\text { Collective } \\
\text { production }+ \\
\text { expertise }\end{array}$ & $\begin{array}{l}\text { Collective } \\
\text { production }+ \\
\text { expertise }\end{array}$ \\
\hline AO & $\begin{array}{l}\text { Isolated local } \\
\text { learning } \\
\text { (participants) } \\
\text { Mode } 1\end{array}$ & $\begin{array}{l}\text { Double loop } \\
\text { learning } \\
\text { Behavioural } \\
\text { learning } \\
\text { Mode 1 }\end{array}$ & $\begin{array}{l}\text { Double loop } \\
\text { learning } \\
\text { Behavioural } \\
\text { learning } \\
\text { Mode 1 }\end{array}$ & $\begin{array}{l}\text { Cognitive learning } \\
\text { Mode } 2\end{array}$ & $\begin{array}{l}\text { Double loop } \\
\text { learning } \\
\text { Well-rounded } \\
\text { organizational } \\
\text { learning } \\
\text { Mode } 2\end{array}$ & $\begin{array}{l}\text { Double loop } \\
\text { learning } \\
\text { Well-rounded } \\
\text { organizational } \\
\text { learning Mode } 2\end{array}$ \\
\hline
\end{tabular}

\section{Conclusion}

Our analysis of current foresight practices led to a review of the typology developed from Bootz (2003)'s and Bootz and Monti (2008)'s exploratory work that now includes two new approaches (operational change management and operational focus), reflecting the new trend towards a shift from strategic to operational practices. The new typology thus underscores the potential extension of the fields of action of these strategic thinking processes as well as the impact on organizational learning. There has been an overall trend towards broader mobilization that is more open to external input. Foresight approaches thus embrace more and more network measures that involve all of the stakeholders (clients, suppliers, users, competitors...). In parallel to increased mobilization, stronger links have developed between reflection and action (both strategic and operational). This shift is significant as, 10 years ago, approaches that combined impact on action and participation were clearly in the minority. The change may be partially explained by the arrival of a new business context based on knowledge 
and innovation, which led to greater maturity of business organisations in terms of knowledge management. It was accompanied by approaches and methods that aimed for more flexibility, openness and rapidity.

By insisting on the participative dimension and collective mobilization, this new trend helps to maintain the French approach in a form that is unique compared to the foresight practices applied across the Atlantic, even if, at the same time, the search for flexibility and the relinquishing of a battery of structured instruments has led to a form of convergence between the two approaches. The present study takes recent changes in foresight practices into account, but also identifies areas of potential change. Thus, the trend towards more extensive mobilization and a more open stance with respect to the outside could pick up speed, prompted by technologies (Web 2.0, crowdsourcing, social media) which support the knowledge economy by promoting the emergence of new foresight methodologies (Radford, 2015).

In focusing our analysis on CNAM community practices, our findings cannot claim to be representative of all the approaches that make up what is generally known as the French school of foresight. Completing our analysis with approaches used in other foresight spheres could be an interesting avenue for future research. Another logical extension of our work could be to compare the French approach with international ones, especially those used in the USA (corporate and foresight).

\section{Appendix: List of cases 2005/2015}

\begin{tabular}{|c|c|c|c|}
\hline Case & Organisation/sponsor & Foresight reflection topics & Years \\
\hline \multicolumn{4}{|c|}{ DECISION-MAKING SUPPORT } \\
\hline French police (ageing) & $\begin{array}{l}\text { Ministry of Defence, National } \\
\text { Gendarmerie }\end{array}$ & 'The ageing population and jobs for seniors in the armed forces' & 2008 \\
\hline FDJ (gambling games) & Française des jeux & 'Gambling games in the world of mobiles in France for $2015^{\prime}$ & 2011 \\
\hline $\begin{array}{l}\text { contract prospective } \\
\text { study building sector } \\
\text { région of Paris i(le de } \\
\text { France) }\end{array}$ & Directte Ile de France & $\begin{array}{l}\text { 'Employment and skills needs linked to work on the New Grand Paris } \\
\text { and challenges of the energy transition In buildings in Île-de-France.' } \\
2014\end{array}$ & 2014 \\
\hline $\begin{array}{l}\text { Assistance observatory } \\
\text { (job sectors and digital) }\end{array}$ & $\begin{array}{l}\text { Observatory of assistance jobs } \\
\text { qualifications and occupational } \\
\text { equality }\end{array}$ & $\begin{array}{l}\text { 'Impact of ITC on employment, working conditions and activity flows } \\
\text { in the field of assistance for } 2025 \text {-Jobs foresight.' }\end{array}$ & 2015 \\
\hline $\begin{array}{l}\text { Bank of France foresight } \\
\text { activities }\end{array}$ & Bank of France & Studies about organization about foresight activities & 2015 \\
\hline \multicolumn{4}{|c|}{ MOBILIZATION 1} \\
\hline Preventative archeology & $\begin{array}{l}\text { Ministry of culture, archeology } \\
\text { department }\end{array}$ & Preventative archeology in France for 2010-2015 & 2005 \\
\hline BASF Agro circle & $\begin{array}{l}\text { BASF Agro France, with around } \\
\text { fifty professional partners from }\end{array}$ & Seven foresight topics dealt with since $2005^{13}$ & $\begin{array}{l}\text { From } 2005 \text { to } \\
2015\end{array}$ \\
\hline
\end{tabular}

13

13 List of topics dealt with by the BASF prospective circle since 2004: Six months after the Luxembourg "certainties and uncertainties" agreements for the farming sector: what impact on farmers' behaviours? (2004) - Horizon 2008: What techniques will be used for French farm production in the future? (2005) - Comparative study of competiveness between the main French production areas compared to other continents. Analysis of the impact, challenges and room for manoeuvre for sector players (2006-2007) - Possible mutations and disruptions for French agriculture by 2015 in terms of sustainable development and their impact on business governance (2008-2009) - Conditions of emergence and the possible content of an analysis on the extended performance of agriculture (2010-2011) - The main prospective dynamics of key competitiveness factors of arable crop production in France in the different markets for 2020-2025 (2012-2013) - The digital revolution and arable crop production for 2025 (20142015). 


\begin{tabular}{|c|c|c|c|}
\hline & $\begin{array}{l}\text { the arable farming production } \\
\text { sector }\end{array}$ & & \\
\hline $\begin{array}{l}\text { SODIAAL (balancing } \\
\text { dairy) }\end{array}$ & SODIAAL & $\begin{array}{l}\text { 'Foresight for the offer/demand balance of dairy resources for } 2010- \\
2014 \text { ' }\end{array}$ & 2009 \\
\hline $\begin{array}{l}\text { GDF SUEZ high } \\
\text { potentials } 1 \text { and } 2 \text { ) }\end{array}$ & GDF SUEZ BU CH\&P & $\begin{array}{l}\text { 'Towards a sober society in France and Europe for 2025: training - } \\
\text { action in strategic foresight for high potential executives,' } 2011 \\
\text { ITC and activity of the CH\&P BU for 2020: training -action in strategic } \\
\text { foresight for high potential executives,' }\end{array}$ & 2010 \\
\hline $\begin{array}{l}\text { USH Social Housing } \\
\text { Union }\end{array}$ & USH & $\begin{array}{l}\text { Three regional approaches pending. Key factors that impact on the } \\
\text { future of social housing organisations for 2025: Midi-Pyrénées, Haute- } \\
\text { Marne, Champagne-Ardenne. }\end{array}$ & 2011,2012 \\
\hline $\begin{array}{l}\text { IRSTEA Environmental } \\
\text { research }\end{array}$ & IRSTEA & Research and innovation for the environment in 2030 & 2012 \\
\hline $\begin{array}{l}\text { Haute-Marne nuclear } \\
\text { waste landfill }\end{array}$ & CCI Haute-Marne & $\begin{array}{l}\text { Long-term management of radioactive waste in the territorial dynamic of } \\
\text { Haute-Marne for 2025: a major challenge and avenues for action }\end{array}$ & 2014 \\
\hline \multicolumn{4}{|c|}{ MOBILIZATION 2} \\
\hline Agora 2020 & $\begin{array}{l}\text { Ministry of Equipment, Centre } \\
\text { of foresight and scientific and } \\
\text { technology intelligence }\end{array}$ & $\begin{array}{l}\text { Agora 2020: live, inhabit, travel in } 2020, \text { what priorities for research?. } \\
\text { Very open process: several formal groups of players (citizens, local } \\
\text { public entities, State, business organisations...) to explore trends, } \\
\text { prioritize key factors, identify common challenges and explore potential } \\
\text { solutions with respect to the present situation. }\end{array}$ & 2004 to 2008 \\
\hline $\begin{array}{l}\text { SEM Federation (local } \\
\text { public company } \\
\text { federation) }\end{array}$ & SEM Federation & The future of mixed economy businesses for 2015 & 2006 \\
\hline $\begin{array}{l}\text { School of architecture in } \\
\text { Toulouse: job sectors }\end{array}$ & $\begin{array}{l}\text { Ministry of Employment, Midi- } \\
\text { Pyrénées region, National } \\
\text { School of Architecture, } \\
\text { Toulouse }\end{array}$ & 'Changing jobs and related training in architecture,'. & 2008 \\
\hline INPES (Health 2030) & INPES & $\begin{array}{l}\text { Health Foresight } 2030 \text { - Prevention (Bipe in collaboration with the } \\
\text { Gerpa- }\end{array}$ & 2010 \\
\hline Health Innovation 2025 & LEEM and AVISAN & $\begin{array}{l}\text { Health 2025: a world of innovations - a debate with all stakeholders for } \\
\text { an ambitious innovations policy to develop an attractive, efficient and } \\
\text { well-balanced health system service. Approach initiated and supported } \\
\text { by the drugs companies }\end{array}$ & 2012 \\
\hline $\begin{array}{l}\text { CNAM } 2020 \text { (adult } \\
\text { formation) }\end{array}$ & CNAM & Jobs, skills and training foresight for 2020. & 2012 \\
\hline $\begin{array}{l}\text { Acta agricultural } \\
\text { research } 2025\end{array}$ & ACTA & Agricultural R\&D systems in France for 2025 & 2014 \\
\hline RTE (operations jobs - 4) & RTE - Operations department & $\begin{array}{l}\text { What will operations jobs be like by } 2025-2030 \text { ? Jobs in farming and } \\
\text { work stations maintenance, Asi and liaisons }\end{array}$ & 2015 \\
\hline
\end{tabular}

OPERATIONAL FOCUS

\begin{tabular}{|c|c|c|c|}
\hline $\begin{array}{l}\text { VEOLIA (urban water } \\
\text { services) }\end{array}$ & $\begin{array}{l}\text { VEOLIA, Direction de urban } \\
\text { water services and Veolia } \\
\text { Institute }\end{array}$ & $\begin{array}{l}\text { Foresight on urban water services for } 2015 \text { in large urban } \\
\text { conglomerations ( }\end{array}$ & 2005 \\
\hline $\begin{array}{l}\text { Vétoquinol antibacteria } \\
2020\end{array}$ & Vétoquinol & $\begin{array}{l}\text { Antibacteria in farm animal production in Europe for } 2020 \text {. A process of } \\
\text { formal exploratory foresight, exploration of strategic challenges, short to } \\
\text { medium term operational learning: key foresight system, factors, key } \\
\text { hypotheses, SWOT analyses on a number of trends/areas or key topics. }\end{array}$ & 2006 \\
\hline Molecule industry Valley & Lyon CCI & $\begin{array}{l}\text { The CCIL (Chamber of Commerce and Industry of Lyon) began a } \\
\text { foresight reflection to explore possible diversification options for the } \\
\text { chemical industry in Lyon and the Rhône-Alpes. This reflection } \\
\text { postulates the conservation and development of expertise in the molecules } \\
\text { industry based on the Lyon melting pot. }\end{array}$ & 2007 \\
\hline 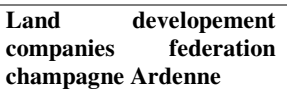 & FNSAFER Champagne Ardenne & Foresight of agricultural activities and impact on investment land policies & $2008-2010$ \\
\hline \multicolumn{4}{|l|}{ Strategic focus } \\
\hline Renault Agriculture & Renault Agriculture & $\begin{array}{l}\text { Foresight of farm machinery for } 2015 \text {, strategic options for the Renault } \\
\text { Group }\end{array}$ & 2005 \\
\hline $\begin{array}{l}\text { Compo et sustainable } \\
\text { development }\end{array}$ & COMPO & $\begin{array}{l}\text { The meaning of sustainable development for COMPO and strategic } \\
\text { solutions for } 2010\end{array}$ & 2007 \\
\hline $\begin{array}{l}\text { Crédit Agricole bank } \\
\text { (consumer credit) }\end{array}$ & $\begin{array}{l}\text { Crédit Agricole, Consumer } \\
\text { credit division }\end{array}$ & $\begin{array}{l}\text { CA Consumer Finance in 3-5 years: anticipating and finding solutions to } \\
\text { future challenges (2010) }\end{array}$ & 2010 \\
\hline Grant Thornton & Grant Thornton & $\begin{array}{l}\text { Foresight on the competitive environment and future challenges for } \\
\text { Grant Thornton (2014) }\end{array}$ & 2014 \\
\hline
\end{tabular}

OPERATIONAL CHANGE MANAGEMENT 1

\begin{tabular}{lll}
\hline $\begin{array}{l}\text { Brittany chambres of } \\
\text { agriculture }\end{array}$ & Brittany chambers of agriculture & The role and missions of chambers of agriculture in Brittany by 2020. \\
\hline $\begin{array}{l}\text { Roadmap 2011/2014 Maiz } \\
\text { Europe }\end{array}$ & Maiz Europe & $\begin{array}{l}\text { Roadmap for MAIZ' EUROP' drawn up according to the changes in the 2011 to 2014 } \\
\text { institutional environment policies and available resources. Used as the } \\
\text { strategy's pilot tool. Resources concentrated on a more effective sector } \\
\text { and inter-sector structure of actions and resources in the following areas: } \\
\text { business techniques, communications policies and relations with } \\
\text { members }\end{array}$ \\
\hline BD Jobs foresight (3) & Becton Dickinson France & $\begin{array}{l}\text { Management foresight on jobs and skills for customer service jobs 2012. } \\
\text { Foresight management of jobs and skills for R\&D and sales jobs. }\end{array}$
\end{tabular}




\begin{tabular}{|c|c|c|c|}
\hline $\begin{array}{l}\text { Groupama and } \\
\text { businesses }\end{array}$ & Groupama & $\begin{array}{l}\text { Drawing up a new framework to understand the impact of the dynamic } \\
\text { development of regions on regional branch development in the short, } \\
\text { medium and long term }\end{array}$ & 2015 to 2017 \\
\hline \multicolumn{4}{|c|}{ OPERATIONAL CHANGE MANAGEMENT 2} \\
\hline $\begin{array}{l}\text { CNIEL (milk industrial } \\
\text { federation }\end{array}$ & CNIEL & Milk, dairy products and businesses in France for 2025. & 2011 \\
\hline FGE genetic breeding & FGE & $\begin{array}{l}\text { Short and medium-term context and perspectives of European genetic } \\
\text { improvement systems for cattle in France and Europe. }\end{array}$ & 2015 \\
\hline Firms, jobs diasbilitiy & $\begin{array}{l}\text { Firms, public organisations and } \\
\text { non governmental organisations }\end{array}$ & The future of firms, work and jof of disability people : policies & 2016 \\
\hline \multicolumn{4}{|c|}{ STRATEGIC CHANGE MANAGEMENT 1} \\
\hline Seine estuaary & $\begin{array}{l}\text { Seine Normandie water agency } \\
\text { and the prefecture of the Haute- } \\
\text { Normandie region }\end{array}$ & $\begin{array}{l}\text { Foresight approach to the Seine estuary for } 2025 \\
\text { See AESN website: } \text { http://www.eau-seine- } \\
\text { normandie.fr/index.php?id=4949 }\end{array}$ & $2004-2005$ \\
\hline $\begin{array}{l}\text { Fondation d'Auteuil } \\
\text { training for young people }\end{array}$ & $\begin{array}{l}\text { Fondation des apprentis } \\
\text { d'Auteuil }\end{array}$ & $\begin{array}{l}\text { The future offer of pre-professional and professional training for young } \\
\text { people over } 14 \text { years of age admitted to the institutions of the Fondation } \\
\text { d'Ile de France, Centre and Nord regions. }\end{array}$ & $2004-2005$ \\
\hline $\begin{array}{l}\text { CFDT Federation of } \\
\text { Banks } 1\end{array}$ & CFDT Banks & $\begin{array}{l}\text { 'Evolutions in employment, qualifications and work conditions in the } \\
\text { banking sector, their impact for the CFDT Federation of banks and } \\
\text { finance companies,and avenues for the organisation's response } \\
\text { strategies.' }\end{array}$ & 2006 \\
\hline $\begin{array}{l}\text { SCET/SEM urban } \\
\text { parking }\end{array}$ & SEM network of SCET parking & SCET 'urban parking foresight in France for 2020,' & 2009 \\
\hline $\begin{array}{l}\text { Chauvet Cave and } \\
\text { Unesco label }\end{array}$ & $\begin{array}{l}\text { Foresight discussions with the } \\
\text { participative body of the Grotte } \\
\text { Chauvet in a bid to obtain the } \\
\text { Unesco label }\end{array}$ & $\begin{array}{l}\text { These foresight discussions resulted in two tangible outcomes: } \\
\text { - a vision for } 2020 \text { of the potential UNESCO action plan } \\
\text { - the formulation of fifteen strategic recommendations for the medium and } \\
\text { long term UNESCO management strategy. }\end{array}$ & 2010 \\
\hline $\begin{array}{l}\text { The future of the land } \\
\text { army } 2025\end{array}$ & DGA, Land army & 'Foresight on jobs in the Land army for 2025 (Future land army forces),' & 2011 \\
\hline $\begin{array}{l}\text { Chamber of agriculture } \\
\text { Britanny R\&D }\end{array}$ & $\begin{array}{l}\text { Brittany regional chamber of } \\
\text { agriculture }\end{array}$ & $\begin{array}{l}\text { Research and development in the chambers of agriculture in Brittany for } \\
\text { 2010: main challenges and strategic options } 2012\end{array}$ & 2012 \\
\hline \multicolumn{4}{|c|}{ STRATEGIC CHANGE MANAGEMENT 2} \\
\hline $\begin{array}{l}\text { French development } \\
\text { agency AFD } 2025\end{array}$ & $\begin{array}{l}\text { AFD, French development } \\
\text { agency }\end{array}$ & $\begin{array}{l}\text { AFD } 2025 \text { - foresight approach with scenario and questionnaire about } \\
\text { world futur of development and possible impact on agency stratégy. }\end{array}$ & 2016 \\
\hline $\begin{array}{l}\text { Cerebral palsy fondation } \\
\text { research }\end{array}$ & $\begin{array}{l}\text { Fondation Motrice, Association } \\
\text { for help with research into } \\
\text { disability, CNSA }\end{array}$ & $\begin{array}{l}\text { Needs and expectations of patients with cerebral palsy and their relations } \\
\text { for } 2020{ }^{\circ} \text { and questions regarding research. }\end{array}$ & 2009 \\
\hline $\begin{array}{l}\text { CFDT Federation of } \\
\text { Bank and insurance } 2\end{array}$ & CFDT bank and insurance 2 & $\begin{array}{l}\text { Evolutions in the DES bank and insurance sectors until 2025, their } \\
\text { impact on the banks and insurance companies federation and their } \\
\text { action strategies }\end{array}$ & 2016 \\
\hline
\end{tabular}

\section{Références}

Alavi M., Kayworth T.R., Leidner D.E., 2005. An Empirical Examination of the Influence of Organizational Culture on Knowledge Management Practices. Journal of Informaions Systems, 22 (3), 191-224.

Albors, J., Ramos, J.C., Hervas, J.L. 2008. New Learning Network Paradigms: Communities of Objectives, Crowdsourcing, Wikis and Open Source. International Journal of Information Management. 28, 194-202.

Argyris, C., Schön, D.A., 1978. Theory in Practice : Increasing Professional Effectiveness, JosseyBass, San Francisco.

Ben Martin, R., 2010. The origins of the concept of 'foresight' in science and technology: An insider's perspective. Technol. Forecast. Soc. Chang. 77, 1438-1447.

Blackwell Pub, Malden, MA, USA.

Boe-Lillegraven, S., Monterde, S., 2015. Exploring the cognitive value of technology foresight: The case of the Cisco Technology Radar.Technol. Forecast. Soc. Chang. 101 62-82.

Bogenrieder, I., Noteboom, B., 2004. Learning Groups: What Types are There ? A Theoretical Analysis and an Emprical Study in a Consultant Firm. Organization Studies. 25, 287-313.

Bootz, J.P. 2005. La prospective un outil de création de connaissances : perspective cognitive et observation participante. Finance Contrôle Stratégie. 8(3), 5-27.

Bootz, J.P., 2003. Prospective appliquée, création de connaissances et apprentissage organisationnel : Construction d'un modèle explicatif fondé sur une approche cognitive. Thèse de doctorat, CNAM. 
Bootz, J.P., 2010, Strategic Foresight and Organizational Learning : Survey and Critical Analysis Technol. Forecast. Soc. Chang. 77 (2010), 1588-1594.

Bootz, J.P., 2015. Comment concilier auto-organisation et contrôle au sein des communautés de pratique pilotées ? : une scoping review. Management International.19 (3), 15-30.

Bootz, J.P., Kern, F., 2009. Les communautés en pratique : leviers de changements pour l'entrepreneur et le manager, Traité Management et Gestion des STIC. Hermès Science Publications- Lavoisier, Paris (France).

Bootz, J.P., Monti, R., 2008. Les démarches prospectives : de l'aide à la décision à la conduite du changement. Construction d'une typologie interprétative en termes d'apprentissage organisationnel. Finance Contrôle stratégie. 11, (1), 41-70.

Brown, J.S., Duguid, P., 1991. Organizational Learning and Communities of Practice: Toward a Unified View of Working, Learning and Innovation. Organization Science. 2 (1), 40-57.

Cagnin, C., Keenan, M., 2008. Positioning future-oriented technology analysis. In: Cagnin, C., Keenan, M., Johnston, R., Scapolo, F., Barré, R. (Eds.), Future oriented Technology Analysis. Strategic Intelligence for an Innovative Economy. Springer, Berlin Heidelberg, 1-13.

Chapuy, P, Gros., V., 2010. Collectively foreseeing future issues: Prospective strategy contributes to the Agriculture and Food Systems' 'Futures Studies' Club. Technol. Forecast. Soc. Chang. 77, 15401545.

Chesbrough, H., 2003. The Era of Open Innovation. Sloan Management Review. 44 (3), 35-41.

Coates, J.F., 2010. The future of foresight. A US perspective. Technol. Forecast. Soc. Chang. 77, $1428-1437$

Cohendet, P., Créplet, F., Dupouët, O., 2001. Organizational Innovation, Communities of Practice and Epistemic Communities : the Case of Linux. in A., Kirman, J.B., Zimmermann (Eds.). Economics with Heterogeneous Interacting Agents. Springer, 303-326.

Cohendet, P., Créplet, F., Dupouet, O., 2006. La gestion des connaissances; firmes et communautés de savoir. Economica.

Cohendet, P., Diani, M., 2003. L'organisation comme une communauté de communautés : croyances collectives et culture d'entreprise. Revue d'Economie Politique. 5, 697-721.

Cowan, R., David, P., Foray, D., 2000. The Explicit Economics of Knowledge Codification and Tacitness. Industrial and Corporate Change. 9 (2), 211-253.

Dean, A., Kretschmer, M., 2007. Can Ideas be Capital? Factors of Production in the Postindustrial Economy: A Review and Critique. Acad. Manag. Rev. 32 (2), 573-594.

Dufva, M., Ahlqvist, T., 2015. Knowledge creation dynamics in foresight: A knowledge typology and exploratory method to analyse foresight workshops. Technol. Forecast. Soc. Chang. 94, 251-268.

Duncan, R.B., 1974. Modifications in Decision Structure in adapting to the Environment: some Implications for Organizational Learning. Decision Sciences. 5, 705-725.

Durance, P., 2010. Reciprocal influences in future thinking between Europe and the USA. Technol. Forecast. Soc. Chang. 77, 1469-1475.

Easterby-Smith, M., Crossan, M., Nicollini, D., 2000. Organizational Learning : Debate Past, Present and Future. Journal of Management Studies. 37 (6), 783-796.

Farsan, M., Rizi, R., \& Shahram, A., 2013. Relationship Between Knowledge Management and Organizational Learning Among Physical Education Teachers », European Journal of Experimental Biology. 3 (1), 526-530.

Fiol, C.M., Lyles, M., 1985. Organizational Learning, Academy of Management Review. 10 (4), 803813.

Foray D., Gault F., 2003. Measuring Knowledge Management in the Business Sector. OCDE.

Fransman, M., 1994. Information, Knowledge, Vision and Theories of the Firm. Industrial and Corporate Change. 3 (3), 713-757.

Garvin, D.A., Edmondson, A.C., Gino, F., 2008. Is yours a learning organization? Harvard Business Review. 86(3), 109-116.

Glick, M., Chermack, T., Luckel, H., Gauck, B., 2012. The effects of scenario planning on participant mental model styles, Eur. J. Train. Dev. 36 (5), 488-507.

Godet, M., 2010. Future memories. Technol. Forecast. Soc. Chang. 77, 1457-1463.

Godet, M., 2007. Manuel de prospective stratégique. Dunod, 3eme édition. 
Haeffner, M., Leone, D., Coons, L., Chermack, T., 2012. The effects of scenario planning on perceptions of learning organization characteristics, Hum. Resour. Dev. Q. 23 (4), 519-542.

Haegeman, K.,Marinelli, E., Scapolo, F., Ricci, A., Sokolov, A., 2013. Quantitative and qualitative approaches in future-oriented technology analysis (FTA): From combination to integration? Technol. Forecast. Soc. Chang. 80 (3), 386-397.

Lave, J., 1988. Cognition in Practice : Mind, Mathematics, and Culture in everyday life. Cambridge University Press.

Levitt, B., March, J., 1988. Organizational Learning. Annual Review of Sociology. 14, 319-340.

Lüdeke,M., 2013. Bridging qualitative and quantitativemethods in foresight. In:cGiaoutzi, M., Sapio, B. (Eds.), Recent developments in foresight methodologies. Springer, New York, pp. 53-66.

Malanowski, N., Zweck, A., 2007. Bridging the gap between foresight and market research: Integrating methods to assess the economic potential of nanotechnology. Technol. Forecast. Soc. Chang. 74 (9), 1805-1822.

Miles, I., 2010. The development of technology foresight: A review. Technol. Forecast. Soc. Chang. $77,1448-1456$.

Miles, I., Harper, J.C., Georghiou, L., Keenan,M., Popper, R., 2008. Themany faces of foresight. In: Georghiou, L., Harper, J.C., Keenan, M., Miles, I., Popper, R. (Eds.), The Handbook of Technology Foresight. Edward Elgar Publishing Limited, Massachusetts, USA, 3-43.

Nooteboom, B. 2006. Cognitive distance in and between COP's and firms: where do exploitation and exploration take place, and how are they connected ?. Paper for DIME workshop on Communities of Practice, Durham, 27-28 October.

Paliokaitè, A., Pačèsa, N., 2015. The relationship between organisational foresight and organisational ambidexterity. Technol. Forecast. Soc. Chang. 101, 165-181

Popper, R., 2008. How are foresight methods selected?. Foresight. 10 (6), 62-89.

Powell, W.W., Snellman, K., 2004. The Knowledge Economy. Annu. Rev. Sociol. 30, 199-220.

Prugsamatz, R., 2010. Factors that Influence Organization Learning Sustainability in Non-profit Organizations. The Learning Organization. 17 (3), 243-267.

Pun, K., Nathai-Balkissoon, M., 2011. Integrating Knowledge Management into Organizational Learning Models: A Review of Concepts and Models. The Learning Organization. 18 (3), vol. 18, n³,

203-223.Raford, N., 2015, Online foresight platforms: Evidence for their impact on scenario planning \& strategic foresight. Technol. Forecast. Soc. Chang. 97, 65-76.

Rhisiart, M, Miller, R., Brooks, S., 2015. Learning to use the future: developing foresight capabilities through scenario processes. Technol. Forecast. Soc. Chang. 101, 124-133

Ringland, G., 2010. The role of scenarios in strategic foresight. Technol. Forecast. Soc. Chang. 77, 1493-1498.

Rohrbeck, R., Battistella, C., Huizingh, E., 2015. Corporate foresight: An emerging field with a rich tradition, Technol. Forecast. Soc. Chang. 101, 1-9.

Rohrbeck, R., Schwarz, J.O., 2013. The value contribution of strategic foresight: Insights from an empirical study of large European companies. Technol. Forecast. Soc. Chang. 80 (8), 1593-1606.

Serenko, A., Dumay, J., 2015. Citation classics published in Knowledge Management Journals, Part I: articles and their characteristics. Journal of Knowledge Management. 19 (2), 401-431.

Spender J.C., 2008. Organizational Learning and Knowledge Management : Whence and Whither ? Management Learning, 39 (2), 159-176.

Tsoukas, H., Shepherd, J., 2004a. Managing the Future: Foresight in the Knowledge Economy.

Tsoukas, H., Shepherd, J., 2004b. Coping with the future: developing organizational foresightfulness. Futures. 36, 137-144.

Uotila, T.,Melkas, H.,Harmaakorpi, V., 2005. Incorporating futures research into regional knowledge creation and management. Futures 37 (8), 849-866.

Valaskakis, K., 2010. Notes on relativity in future studies Technol. Forecast. Soc. Chang 77, 1464 1468.

Vecchiato, R., 2015. Creating value through foresight: First mover advantages and strategic agility. Technol. Forecast. Soc. Chang. 101, 25-36

Ventriss, C., Luke, J., 1988. Organizational Learning and Public Policy: Towards a Substantive Perspective. American Review of Public Administration. 18 (4), 337-357. 
Vishnevskiy K., Karasev O., Dirk Meissner D., 2015. Integrated roadmaps and corporate foresight as tools of innovation management: The case of Russian companies, Technol. Forecast. Soc. Chang. 90, 433-443

Von der Gracht, H.A., Bañulsb, V.A., Turoff, M., Andrzej M., Skulimowski, A.M.J., Gordone, T.J., 2015. Foresight support systems: The future role of ICT for foresight. Technol. Forecast. Soc. Chang. $97,1-6$.

Watzlavawitch, P., 1991. La réalité de la réalité : confusion, désinformation, communication. Editions du Seuil, 1991.

Weick, K.E., 2005. Managing the future: foresight in the knowledge economy. Acad. Manag. Rev. 30, 871-873.

Wenger, E., 1998. Communities of Practice : Learning, Meaning and Identity, Cambridge. MA : Cambridge University Press.

Jean-Philippe Bootz is Assistant Professor and Head of the Corporate Chair in Knowledge Management at the EM Strasbourg Business School of the University of Strasbourg and as well as a researcher at HuManiS (Humans and Management in Society). His scientific interests are in the fields of strategic foresight and knowledge management. He published several articles on these subjects in different academic journals such as Technological Forecasting and Social Change, Knowledge Management Research and Practice, Journal of Knowledge Management, Management International...

Philippe Durance is Professor at CNAM-LIRSA (Laboratoire interdisciplinaire de recherche en sciences de l'action) and Head of the Foresight and Sustainable Development Department of CNAM. His scientific interests are in the fields of foresight, innovation, sustainable development and history of the public decision. He is also an expert in foresight and innovation for the State and the local authorities, and is in charge of the "Prospective" collection of Harmattan editions. He published several books and articles on foresight subjects.

Régine Monti is Associate Director at GERPA (Groupe Ressources Prospective) and Associate Professor at LIRSA (CNAM). She has been in charge for almost twenty year actions of training - action and manage missions of foresight and strategy with companies, local authorities, ministries and other public bodies. She is specialized on the foresight questions connected to employment, training and human resources management. She acted as an expert adviser in this matters in diverse committees.

Vincent Pacini is Associate Director at GERPA (Groupe Ressources Prospective) and Associate Professor at PACTE (CNAM). He steers various consulting missions and is involved in several corporate development plans (ANPE, APM, BASF, CFDT, Commissariat Général au Plan, DATAR, EDF, MAIF, Ministère du Tourisme, UNIL, General Council of Gironde, Regional Council of Ile de France, COCPIT,...). His research interests include the links between strategic foresight, knowledge production and change.

Pierre Chapuy is Director of Studies and associate at GERPA (Groupe Ressources Prospective), as well as a research fellow at LIRSA (CNAM). He realized numerous works on foresight and strategic thinking in the field of environment and sustainable development for industrial groups or for public authorities such as EDF, Renault, BASF, Veolia... 